\title{
Penerapan Strategi Pelaksanaan (SP) 1-4 Dengan Halusinasi Pada Penderita Skizofrenia: Studi Kasus
}

\author{
Sasmita Sasmita \\ Sasmitamita0199@gmail.com
}

\section{BAB 1}

PENDAHULUAN

\subsection{Latar Belakang}

Skizofrenia merupakan suatu gangguan jiwa berat yang bersifat kronis yang ditandai dengan ganggguan komunikasi, gangguan realitas, afek tidak wajar atau tumpul, gangguan fungsi kognitif serta mengalami kesulitan dalam melakukan aktivitas sehari-hari (Pardede, 2020). Skizofrenia salah satu bentuk gangguan jiwa kronik, yang menyebabkan penyakit otak persisten serius yang mengakibatkan perilaku psikotik, pemikiran konkret, dan kesulitan dalam memperoleh informasi. (Pardede \& Hasibuan, 2020). Skizofrenia menimbulkan distorsi pikiran, distorsi persepsi, emosi, dan tingkah laku sehingga pasien dengan skizofrenia memiliki resiko lebih tinggi berperilaku agresif dimana perubahan perilaku secara dramatis terjadi dalam beberapa hari atau minggu sehingga bisa menyebabkan halusinasi. Skizofrenia merupakan sekelompok reaksi psikotik yang mempengaruhi berbagai area fungsi individu, termasuk berfikir, berkomunikasi, merasakan dan menunjukkan emosi serta gangguan otak yang ditandai dengan pikiran kacau, waham, halusinasi, dan perilaku aneh (Rhoad, 2011; Pardede, Silitonga \& Laia, 2020).

Menurut WHO (2019) Skizofrenia merupakan suatu gangguan jiwa berat yang bersifat berat dan kronis yang menyerang 20 juta orang di seluruh dunia. Skizofrenia merupakan penyakit kronis, parah, dan melumpuhkan, gangguan otak yang di tandai dengan pikiran kacau, waham, delusi, halusinasi, dan perilaku aneh atau katatonik (Pardede \& Laia, 2020). (Riskesdas, 2018). Halusinasi merupakan keadaan seseorang mengalami perubahan dalam pola dan jumlah stimulasi yang di prakarsai secara internal atau eksternal disekitar dengan pengurangan berlebihan,distorsi, atau kelainan berespon terhadap setiap stimulasi (Pardede, Silitonga \& Laia, 2020). Dengan Kekambuhan sebagai akibat dari regimen teraupetik tidak efektif dapat lebih parah dan bahaya dari pada klien gangguan awitan awal (Pardede, 2016). 
Menurut Muspidayanti (2018) pasien halusinasi menjadi menarik diri tidak mau menceritakan hal yang mereka alami karena mereka takut lebih mendapatkan pandangan negative dari orang lain terkait pikiran mereka yang tidak wajar dan penderita skizofrenia yang sembuh dengan pasien harus bertanggung jawab dalam merawat pasien, namun dalam pelaksanaannya hal ini menjadi beban bagi keluarga. Keadaan ini meningkatkan stres dalam keluarga (Manao \& Pardede, 2019).

Berdasarkan Survey yang dilakukan di ruangan Mawar. Diperoleh jumlah pasien rawat inap sebanyak 20 pasien dengan skizofrenia dengan masalah keperawatan gangguan persepsi sensori halusinasi dan harga diri rendah. Tetapi yang menjadi subjek pemberian asuhan keperawatan jiwa Ny.D yang mngalami masalah halusinasi, klien di jadikan sebagai sebagai subjek di karenakan pasien belum bisa mengatasi halusinasinya selain minum obat. Maka tujuan asuhan keperawatan yang akan di lakukan ialah untuk mengajarkan standar pelaksaan (SP 1-4) masalah halusinasi pendengaran pada saat Ny.D mengalami halusinasinya.

\subsection{Tujuan Penulisan}

\subsubsection{Tujuan Umum}

Mahasiswa mampu memberikan Asuhan Keperawatan Jiwa Pada Ny. D dengan Gangguan Halusinasi Pendengaran.

\subsubsection{Tujuan Khusus}

1. Mahasiswa mampu mengetahui defenisi, tanda \& gejala, faktor penyebab, mekanisme koping, penatalaksanaan pada Klien dengan halusinasi pendengaran

2. Mahasiswa mampu melakukan pengkajian pada Klien dengan halusinasi pendengaran

3. Mahasiswa mampu menegakkan diagnosa atau masalah keperawatan pada Ny. D dengan Halusinasi pendengaran

4. Mampu menetapkan intervensi keperawatan secara menyeluruh pada Ny.D dengan Halusinasi pendengaran

5. Mahasiswa mampu melakukan tindakan keperawatan yang nyata pada Ny. D dengan Halusinasi pendengaran

6. Mahasiswa mampu mengevaluasi sebagai tolak ukur guna menerapkan asuhan keperawatan pada Ny. D dengan Halusinasi Pendengaran.

7. Mahasiswa mampu mendokumentasikan asuhan keperawatan pada Ny. D dengan Halusinasi Pendengaran 


\subsection{Manfaat Penulisan}

1. Pasien

Diharapkan Tindakan yang telah diajarkan dapat di terapkan secara mandiri untuk bisa mengontrol Halusinasi untuk mendukung kelangsungan kesehatan pasien.

2. Bagi Rumah Sakit Jiwa

Diharapkan dapat menjadi acuan dalam menangani atau dalam memberikan pelayanan kepeada pasian gangguan jiwa dengan Halusinasi pendengaran di Rumah Sakit Jiwa Prof. Dr. M. Ildrem 


\section{BAB 2}

\section{TINJAUAN TEORITIS}

\subsection{Konsep Halusinasi}

\subsubsection{Defenisi}

Halusinasi adalah distorsi persepsi palsu yang terjadi pada respons neurobiologis maladaptive .Halusinasi biasanya muncul pada pasien gangguan jiwa diakibatkan terjadinya perubahan orientasi realita,pasien meraskan stimulasi yang sebetulnya tidak ada.halusinasi penglihatan dan pendengaran yang merupakan gejala dari early psychosis, yang sebagian besar terjadi pada usia remeja akhir atau dewasa awal,bingung peran yang berdampak pada rapuhnya kepribadian sehingga terjadi gangguan konsop diri dan menarik diri dari lingkungan social yang lambat laun membuat penderita menjadi asik dengan hayalan dan menyebabkan timbulnya halusinasi. (Ervina,2018).

Dampak yang muncul akibat gangguan halusinasi adalah hilangannya control diri yang menyebabkan seseorang menjadi panik dan perilakunya dikendalikan oleh halusinasi.Dalam situasi ini penderita halusinasi dapat melakukan tindakan merusak lingkungan,mencelaki orang lain,bahkan melakukan bunuh diri agar tidak berdampak buruk maka penderita halusinasi harus segera ditangani secara tepat.(Sunarwanto,2017). Berdasarkan beberapa defenisi di atas dapat di ambil kesimpulan bahwa halusinasi merupakan gangguan persepsi panca indera, adanya stimulus ekternal yang merasakan sensasi palsu namun tidak dapat dirasakan oleh orang lain.

\subsubsection{Tanda Dan Gejala Halusinasi}

Tanda dan Gejala Tanda dan gejala halusinasi dinilai dari hasil observasi terhadap pasien serta ungkapan pasien menurut (Oktiviani, 2020) :

1. Menyeringai atau tertawa yang tidak sesuai

2. Menggerakkan bibirnya tanpa menimbulkan suara

3. Gerakan mata cepat

4. Menutup telinga 

5. Respon verbal lambat atau diam
6. Diam dan dipenuhi oleh sesuatu yang mengasyikkan
7. Terlihat bicara sendiri
8. Menggerakkan bola mata dengan cepat
9. Bergerak seperti membuang atau mengambil sesuatu
10. Duduk terpaku, memandang sesuatu, tiba-tiba berlari ke ruangan lain

\subsubsection{Etiologi}

Faktor predisposisi pasien halusinasi menurut ( Oktiviani,2020 ) :

\section{Faktor Predisposisi}

- Faktor perkembangan

Tugas perkembangan pasien terganggu misalnya rendahnya control dan kehangatan keluarga menyebabkan pasien tidak mampu mandiri sejak kecil,mudah frustasi,hilang percaya diri.jika tugas perkembangan menemui hambatan dan hubungan interpersonal terputus, individu akan merasa social dan cemas (Zelika \& Dermawan, 2015).

- Faktor sosiokultural

Seseorang yang merasa tidak diterima dilingkungan sejak bayi akan merasa disingkirkan,kesepian,dan tidak percaya pada lingkungan. Faktor berbagai masyarakat dapat merasa dikucilkan.

- Biologi

Faktor biologis mempunyai pengaruh terhadap terjadinya gangguan jiwa.adanya stress yang berlebihan dialami seseorang maka didalam tubuh akan dihasilkan suatu zat yang dapat bersifat halusinogen neurokimia.Akibat stress berkepanjangan menyebabkan teraktivitasnya neurotransmitter otak. Hal ini berdampak pada terjadinya gangguan jiwa, jika seseorang mengalami sosial yang berlebihan ( Sutejo, 2020).

- Psikologis

Tipe kepribadian lemah dan tidak bertanngung jawab mudah terjerumus pada penyalahgunaan zat adiktif.Hal ini berpengaruh pada ketidakmampuan psien dalam mengambil keputusan yang tepat demi masa depannya,pasien lebih memilih kesenangan sesaat dan lari dari alam nyata menuju alam khayal. Hubungan interpersonal tidak harmonis, dan biasanya seseorang menerima 
berbagai peran yang kontradiktif, yang akan menimbulkan banyak social dan kecemasan, serta berujung pada hancurnya orientasi realitas (Dermawan, 2016).

- Sosial Budaya

Meliputi pasien mengalami interaksi social dalam fase awal dan comfortin,pasien menganggap bahwa hidup bersosialisasi di alam nyata sangat membahayakan.pasien asyik dengan Halusinasinya,seolah-olah ia merupakan tempat untuk memenuhi kebutuhan akan interaksi social,control diri dan harga diri yang tidak didapatkan dalam dunia nyata. Faktor berbagi dalam masyarakat dapat membuat orang merasa kesepian di likungan mereka yang luas (Sutejo, 2020).

1. Faktor Presipitasi

Menurut Prabowo (2014) factor presipita dapat meliputi:

- Biologis

Gangguan dalam komunikasi dan putaran balik otak,yang mengatur proses informasi serta abnormalitas pada mekanisme pintu masuk dalam otak yang mengakibatkan ketidakmampuan untuk secara selektif menanggapi stimulus yang diterima oleh otak untuk diinterpretasikan.

- Stress lingkungan

Ambang toleransi terhadap stress yang berinteraksi terhadap stressor lingkungan untuk menentukan terjadinya gangguan perilaku.

- Sumber koping

Sumber koping mempengaruhi respon individu dalam menanggapi stressor.

\subsubsection{Rentang Respon Neurobiologi}

Rentang repon tersebut dapat digambarkan seperti dibawah ini (Muhith,2015) :

Adaptif

\begin{tabular}{|l|l|}
\hline 1.Pikiran & 1.Distorsi pikiran ilusi \\
2.Persepsi akurat & 2.Reaksi emosi berlebihan \\
3.Emosi konsisten & 3.perilaku aneh atau tidak \\
dengan pengalaman & biasa \\
4.Perilaku sesuai & 4.Menarik diri \\
5.Berhubungan sosial &
\end{tabular}

\section{Mal adaptif}

1.Gangguan piker/delusi

2.Halusinasi

3.Sulit merespon emosi

4.Perilaku disorganisasi

5.Isolasi social 
Keterangan :

a. Respon adaptif adalah respon yang dapat diterima oleh norma-norma social budaya yang berlaku.Dengan kata lain individu tersebut dalam batas normal jika menghadapi suatu akan dapat memecahkan masalah tersebut .

Respon adaptif meliputi :

1) Pikiran logis adalah pandangan yang mengarah pada kenyataan

2) Persepsi akurat adalah pandangan yang tepat pada kenyataan

3) Emosi konsisten dengan pengalaman yaitu perasaan yang timbul dari pengalaman ahli.

4) Perilaku sesuai adalah sikap dan tingkah laku yang masih dalam batas kewajaran.

5) Hubungan social adalah proses suatu interkasi dengan orang lain dan lingkungan.

b. Respon Psikososial Meliputi :

1) Proses piker terganggu yang menimbulkan gangguan

2) Ilusi adalah miss intrerprestasi atau penilaian yang salah tentang yang benar-benar terjadi (objek nyata) karena gangguan panca indra

3) Emosi berlebihan atau kurang

4) Perilaku tidak biasa adalah sikap dan tingkah laku yang melebihi batas untuk menghindari Interaksi dengan orang lain

5) Menarik diri adalah percobaan untuk menghindari hubungan dengan orang lain.

c. Respon maladaptive adalah respon indikasi dalam menyelesaikan masalah yang menyimpang dari norma-norma social dan budaya dan lingkungan,adapun respon maladaptive ini meliputi :

1) Kelainan pikiran adalah keyakinan yang secara kokoh dipertahankan walaupun tidak diyakini oleh orang lain dan bertentangan dengan kenyataan sosail

2) Halusinasi merupakan persepsi sensori yang salah satu atau persepsi eksternal yang tidak realita atau tidak ada.

3) Kerusakan proses emosi adalah perubahan sesuatu yang timbul dari hati

4) Perilaku tak terorganisir merupakan perilaku yang tidak teratur Isolasi social adalah kondisi kesendirian yang dialami oleh individu dan diterima sebagai ketentuan oleh orang lain dan sebagai suatu kecelakaan yang negatif mengancam 


\subsubsection{Klasifikasi Halusinasi}

Menurut Yusuf (2015) klasifikasi halusinasi dibagi menjadi 5 yaitu:

\begin{tabular}{|c|c|c|c|}
\hline No & Jenis halusinasi & Data Objektif & Data Subjektif \\
\hline 1. & $\begin{array}{l}\text { Halusinasi } \\
\text { pendengaran }\end{array}$ & $\begin{array}{l}\text { 1.Bicara atau tertawa sendiri } \\
\text { tanpa lawan bicara } \\
\text { 2.Marah-marah tanpa sebab } \\
\text { mencondongkan telinga kea } \\
\text { rah tertentu } \\
\text { 3.Menutup Telinga }\end{array}$ & $\begin{array}{l}\text { 1.Mendengar suara } \\
\text { atau kegaduhan } \\
\text { 2.Mendengar suara } \\
\text { yang mengajak } \\
\text { bercakap-cakap } \\
\text { 3.Mendengar suara } \\
\text { yang menyuruh } \\
\text { melakukan sesuatu } \\
\text { yang berbahaya }\end{array}$ \\
\hline 2. & $\begin{array}{l}\text { Halusinasi } \\
\text { Penglihatan }\end{array}$ & $\begin{array}{l}\text { 1.Menunjuk-nunjuk ke arah } \\
\text { tertentu } \\
\text { 2.Ketakutan pada objek yang } \\
\text { tindak jelas }\end{array}$ & $\begin{array}{l}\text { 1.Melihat } \\
\text { bayangan,sinar,bentuk } \\
\text { geometris,bentuk } \\
\text { kartun,melihat hantu } \\
\text { atau monster }\end{array}$ \\
\hline 3. & $\begin{array}{l}\text { Halusinasi } \\
\text { Penghidu }\end{array}$ & $\begin{array}{l}\text { 1.Menghidu seperti sedang } \\
\text { membaui bau-bauan tertentu } \\
\text { 2.Menutup hidung }\end{array}$ & $\begin{array}{l}\text { 1.Membaui bau-bauan } \\
\text { seperti bau } \\
\text { darah,urine,feses, } \\
\text { 2.kadang-kadang bau } \\
\text { itu menyengkan }\end{array}$ \\
\hline 4. & $\begin{array}{l}\text { Halusinasi } \\
\text { pengecapan }\end{array}$ & $\begin{array}{l}\text { 1.Sering meludah } \\
\text { 2.Muntah }\end{array}$ & $\begin{array}{l}\text { 1.Merasakan rasa } \\
\text { seperti } \\
\text { darah,uirine,feses }\end{array}$ \\
\hline 5. & $\begin{array}{l}\text { Halusinasi } \\
\text { Perabaan }\end{array}$ & $\begin{array}{l}\text { Menggaruk-garuk permukaan } \\
\text { kulit }\end{array}$ & $\begin{array}{l}\text { 1.Mengatakan ada } \\
\text { serangga di } \\
\text { permukaan kulit } \\
\text { 2.Merasa seperti } \\
\text { tersengat listrik }\end{array}$ \\
\hline
\end{tabular}




\subsection{Konsep Asuhan Keperawatan Jiwa}

\subsubsection{Pengkajian Keperawatan}

Pengkajian adalah proses untuk tahap awal dan dasar utama dari proes keperawatan terdiri drai pengumpulan data dan perumusan kebutuhan atau masalah pasien. Data yang dikumpulkan melalui data biologis, psikologis, sosial dan spiritual. Pengelompokkan data pengkajian kesehatan jiwa, dapat berupa faktor presipitasi, penilaian terhadap stressor, sumber koping, dan kemampuan yang dimiliki (Afnuhazi, 2015).

\subsubsection{Diagnosa Keperawatan}

Dengan faktor berhubungan dan Batasan karakteristik disesuaikan dengan keadaan yang ditemukan pada tiap tiap partisipan. Topik yang diteliti yakni kemampuan mengontrol halusinasi dengar (Aji, 2019).

\subsubsection{Intervensi Keperawatan}

Rencana tindakan pada keluarga (Keliat, 2015) adalah ;

1. Diskusikan masalah yang dihadap keluarga dalam merawat pasien

2. Berikan penjelasan meliputi : pengertian halusinasi, proses terjadinya halusinasi, jenis halusinasi yang dialami, tanda dan gejala halusinasi, proses terjadinya halusinasi.

3. Jelaskan dan latih cara merawat anggota keluarga yang mengalami halusinasi : menghardik, minum obat, bercakap-cakap, melakukan aktivitas.

4. Diskusikan cara menciptakan lingkungan yang dapat mencegah terjadinya halusinasi.

5. Diskusikan tanda dan gejala kekambuhan

6. Diskusikan pemanfaatan fasilitas pelayanan kesehatan terdekat untuk follow up anggota keluarga dengan halusinasi.

\subsubsection{Implementasi Keperawatan}

1. Bina hubungan saling percaya (BHSP)

2. Identifikasi, waktu, frekuensi, situasi, respon pasien terhadap halusinasi 
3. Melatih pasien mengontrol halusinasi dengan cara menghardik

4. Melatih pasien mengontrol halusinasi dengan cara patuh minum obat

5. Melatih pasien dengan cara bercakap-cakap

6. Melatih pasien mengontrol halusinasi dengan cara melaksanakan kegiatan terjadwal (Santi, 2021)

\subsubsection{Evaluasi Keperawatan}

Evaluasi adalah proses hasil atau sumatif dilakukan dengan membandingkan respon pasien pada tujuan umum dan tujuan khusus yang telah ditentukan.halusinasi pendengaran tidak terjadi perilaku kekerasan, pasien dapat membina hubungan saling percaya, pasien dapat mengenal halusinasinya, pasien dapat mengontrol halusinasi dengar dari jangka waktu 4x24 jam didapatkan data subjektif keluarga menyatakan senang karena sudah diajarkan teknik mengontrol halusinasi, keluarga menyatakan pasien mampu melakukan beberapa teknik mengontrol halusinasi. Data objektif pasien tampak berbicara sendiri saat halusinasi itu datang, pasien dapat berbincangbincang dengan orang lain, pasien mampu melakukan aktivitas terjadwal, dan minum obat secara teratur ( Aji, 2019) 


\section{BAB 3}

\section{TINJAUAN KASUS}

\subsection{Identitas Klien}

$\begin{array}{ll}\text { Inisial } & : \text { Ny. D } \\ \text { Ruang Rawat } & : \text { Mawar } \\ \text { Tanggal Pengkajian } & : 07 \text { februari } 2022 \\ \text { Umur } & : 37 \text { Tahun } \\ \text { Agama } & : \text { Islam } \\ \text { Status } & : \text { Janda } \\ \text { Informant } & : \text { Klien dan Buku Status Klien }\end{array}$

\subsection{Alasan Masuk}

Klien masuk ke rumah sakit jiwa di antar oleh kakaknya, sebelumnya klien pernah di rawat di Rumah Sakit Jiwa 6 tahun yang lalu, klien tetapi tidak rutin control dan minum obat, klien di rumah sering berbicara sendiri, mondar-mandir,sering mendengar suara bisikin-bisikin tanpa wujud dan semyum-senyum, tertawa sendiri.

Masalah Keperawatan : Halusinasi pendengaran

\subsection{Faktor Predisposisi}

Klien sebelumnya tidak pernah mengalami gangguan jiwa, awalnya pada tahun 2012 klien depresi karena ibu klien meninggal, mereka bangkrut, kemudian klien menikah setelah menikah satu tahun klien mempunyai anak satu dan klien diceraikan oleh suaminya, klien tinggal bersama orang tua di di daerah binjai, semenjak kejadian itu klien sering marah-marah tidak jelas, berbicara sendiri, merasa dirinya tidak berguna, klien merasa sudah tidak ada yang peduli terhadap dirinya.

\subsection{Fisik}

Klien tidak memiliki keluhan fisik, saat dilakukan pemeriksaan tanda-tanda vital, didapatkan hasil TD : 120/70 mmHg ; N : 80x/i ; S : 36, ${ }^{\circ} \mathrm{C} ; \mathrm{P}: 20 x /$ i. Klien memiliki tinggi badan 160 $\mathrm{cm}$ dan berat badan $45 \mathrm{Kg}$. 


\subsection{Psikososial}

\subsubsection{Genogram}

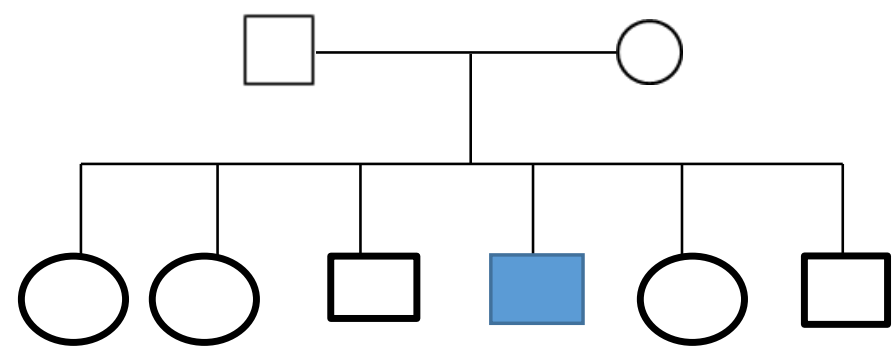

Penjelasan : Klien adalah anak ke 4 dari 6 saudara, sudah menikah

Keterangan :

$\bigcirc$ : perempuan

: laki-laki

: klien

\/ : cerai

$\sqcap$ : garis keturunan

$\sqcup$ : garis perkawinan

: tinggal serumah dengan klien

叉: meninggal

\subsubsection{Konsep diri}

1. Gambaran diri : Klien menyukai semua anggota tubuhnya dan tidak ada yang cacat

2. Identitas : Klien anak ke 4 dari 6 bersaudara, klien lulusan SMP

3. Peran : Klien dirumah biasanya mengerjakan pekerjaan rumah

4. Ideal diri $\quad$ Klien ingin cepat sembuh dan pulang ke rumah.

5. Harga diri : Klien merasa malu karena sakitnya malu di rawat di Rumah Sakit Jiwa dan tidak bisa merawat anaknya

Masalah keperawatan: Gangguan konsep diri : Harga diri rendah 


\subsubsection{Hubungan Sosial}

Klien mengangap keluarganya yang sangat berarti baginyan terutama pada orang tua dan anaknya, klien sebelum sakit selalu ikut pengajian (wirid), klien mengatakan mempunyai Hambatan dalam berhubungan dengan orang lain : Klien merasa malu dan takut serta ada rasa curiga kepada orang lain

\subsubsection{Spiritual}

1) Nilai dan keyakinan : pasien beragama Islam, percaya dan pasrah kepada Allah SWT, yakin bahwa semua sudah diatur. Pasien ingin pulang ke rumah dan berharap keluarga dan masyarakat mau menerima keadaanya.

2) Kegiatan ibadah : pasien mengatakan selalu sholat lima waktu.

\subsubsection{Status Mental}
a. Penampilan

Klien berpenampilan kurang rapi

b. Pembicaraan

Klien masih mampu menjawab pertanyaan dengan jelas tetapi tidak dapat cepat memahami pertanyaan yang diberikan.

c. Aktivitas Motorik

klien dapat melakukan aktivitas dengan baik

d. Suasana perasaan

Klien merasa malu karena sakitnya sehingga tidak bisa merawat anaknya dan merasa minder dengan orang lain.

e. Interaksi selama wawancara

Klien kooperatif, tidak ada kontak mata pada lawan bicara, mudah tersinggung dalam setiap interaksi.

f. Persepsi

Klien sering mendengar suara-suara bisikan aneh memanggil namanya, suara muncul pada setiap siang dan sore 2 kali dalam satu hari

Masalah keperawatan : halusinasi pendengaran 


\section{g. Proses Pikir}

Klien mampu menjawab pertanyaan dengan baik, namun terkadang harus ada pengulangan pertanyaan

h. Isi pikir

Klien dapat mengontrol isi pikirnya,klien tidak mengalami gangguan isi pikir dan tidak ada waham.

i. Tingkat kesadaran Tingkat Kesadaran composmentis klien mengalami sedikit kebinguan gangguan orientasi.

j. Memori

Klien mampu menceritakan kejadian di masa lalu dan yang baru terjadi.

k. Tingkat konsentrasi berhitung

Klien mampu menjawab namun kurang berkonsentrasi

1. Kemampuan penilaian

Klien dapat membedakan hal yang baik dan yang buruk.

m. Daya tilik diri

Klien tidak mengingkari penyakit yang diderita, klien mengetahui bahwa dia sering mendengar suara-suara

\subsection{Mekanisme Koping}

Klien mengalami mekanisme koping adaptif yaitu klien dapat berbicara baik dengan orang lain dan berkooperatif.

\subsection{Masalah Psikososial dan Lingkungan}

Klien mengatakan bangkrut sehingga tidak bisa bekerja karena tidak ada modal lagi untuk berjualan, klien merasa malu karena penyakit sehingga is di rawat di rumah sakit jiwa

\subsection{Pengetahuan Kurang Tentang}

Klien tidak mengetahui tentang gangguan jiwa yang di alaminya, pasien mengatakan jika sedang mengdengar suara-suara bisikan maka menutup telinga.

\subsection{Aspek Medik}

Diagnosa Medik : 
Skizofrenia paranoid

Terapi Medik: Pemberian/minum obat kepada pasien secara teratur.
a. Risperidon (RSP) tablet $2 \mathrm{mg} 2 \times 1$
b. clozapine $25 \mathrm{mg} 1 \mathrm{x} 1$

\subsection{Analisa Data}

\begin{tabular}{|c|c|c|}
\hline No & Data & Masalah Keperawatan \\
\hline 1. & $\begin{array}{ll}\text { DS: } & \\
\text { - } & \text { Klien mengatakan sering mendangar suara } \\
& \text { suara bisikikan tanpa wujud } \\
\text { - } & \text { suara muncul siang dan sore hari } \\
& \text { memanggil namanya } \\
\text { - } & \text { klien merasa gelisih saat suara datang } \\
\text { - } & \text { klien sering mendengar suara itu ketika } \\
& \text { klien sendirian } \\
\text { DO: } & \\
\text { - } & \text { klien tampak sering berbicara sendiri } \\
\text { - } & \text { klien sering berbicara sendiri } \\
\text { - } & \text { klien senyum- senyum sendiri } \\
\text { - } & \text { klien mondar-mandir } \\
\text { - } & \text { klien tampak gelisah } \\
\text { - } & \text { klien tampak brbicara sendiri }\end{array}$ & $\begin{array}{l}\text { Gangguan persepsi } \\
\text { sensori : Halusinasi } \\
\text { pengdengaran }\end{array}$ \\
\hline 2. & $\begin{array}{ll}\text { DS: } & \\
\text { - } & \text { Klien mengatakan merasa malu karena } \\
& \text { penyakitnya, } \\
\text { - } & \text { Klien mengatakan merasa tidak berguna } \\
& \text { karena tidak bisa merawat anaknya } \\
\text { - } & \text { Klien mengatakan merasa minder dengan } \\
& \text { orang lain } \\
\text { - } & \text { Klien mengatakan merasa tidak di hargai }\end{array}$ & $\begin{array}{l}\text { Gangguan konsep diri: } \\
\text { Harga diri rendah }\end{array}$ \\
\hline
\end{tabular}




\begin{tabular}{|c|c|c|c|}
\hline & $\begin{array}{c}\text { DO: } \\
- \\
- \\
- \\
-\end{array}$ & $\begin{array}{l}\text { Klien tampak murung dan malu } \\
\text { Kontak mata kurang } \\
\text { Klien Berbicara lambat } \\
\text { Klien tampak sedih }\end{array}$ & \\
\hline 3. & $\begin{array}{r}\text { DS : } \\
- \\
- \\
- \\
\\
\quad \\
\quad- \\
- \\
-\end{array}$ & $\begin{array}{l}\text { Klien mengatakan jarang mensikat gigi } \\
\text { Mandi jarang menggunkan sabun dan } \\
\text { shampoo } \\
\text { Klien jarang mengganti pakaian } \\
\text { Gigi Klien tampak kuning dan kotor } \\
\text { Penampilan tampak kurang bersih } \\
\text { Rambut tampak kurang rapi }\end{array}$ & Defisit perawatan diri \\
\hline
\end{tabular}

\subsection{Masalah Keperawatan:}

a. Gangguan persepsi sensori : halusinasi pendengaran

b. Gangguan konsep diri : Harga diri rendah

c. Defisit perawatan diri

\subsection{Pohon Masalah}

Defisit perawatan diri

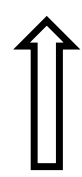

Gangguan persepsi sensori : Halusinasi 


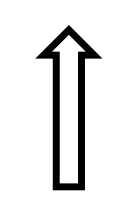

Gangguan konsep diri : Harga diri rendah

\subsection{Prioritas Masalah Keperawatan}

a. Gangguan persepsi sensori : halusinasi pendengaran

\subsection{Intervensi Keperawatan}

\begin{tabular}{|c|c|c|}
\hline No & Diagnosa Keperawatan & Intervensi \\
\hline 1. & $\begin{array}{c}\text { Gangguan persepsi sensori : } \\
\text { halusinasi pendengaran }\end{array}$ & $\begin{array}{l}\text { Sp1 : } \\
\text { 1.identifikasi isi,waktu terjadi,dan respon terhadap } \\
\text { halusinasi } \\
\text { 2.mengontrol halusinasi dengan cara menghardik } \\
\text { Sp2: } \\
\text { Mengontrol halusinasi dengan cara minum obat } \\
\text { secara teratur } \\
\text { Sp3 : } \\
\text { Mengontrol halusinasi dengan cara bercakap-cakap } \\
\text { dengan oang lain } \\
\text { Sp4 : } \\
\text { Mengontrol halusinasi dengan cara melakukan } \\
\text { kegiatan terjadwal }\end{array}$ \\
\hline 2. & $\begin{array}{c}\text { Gangguan konsep diri : } \\
\text { Harga diri rendah }\end{array}$ & $\begin{array}{l}\text { Sp1 : } \\
\text { Mengidentifikasi kemampuan dan aspek positif } \\
\text { yang dimiliki pasien } \\
\text { Sp2 : } \\
\text { a. Menilai } \\
\quad \text { kemampuan yang dapat digunakan } \\
\text { b. Menetapkan atau memilih kegiatan } \\
\text { sesuai kemampuan } \\
\text { c. Melatih kegiatan sesuai kemampuan } \\
\text { yang dipilih } 1\end{array}$ \\
\hline
\end{tabular}




\begin{tabular}{|c|c|c|}
\hline & & $\begin{array}{ll}\text { Sp3 : } & \\
& \text { Melatih kegiatan sesuai kemampuan } \\
& \text { yang dipilih } 2 \\
\text { sp4 : } & \\
& \text { Melatih kegiatan sesuai kemampuan } \\
& \text { yang dipilih } 3\end{array}$ \\
\hline 3. & Defisit perawatan diri & $\begin{array}{l}\text { Sp1 : } \\
\text { Melatih cara perawatan diri : mandi } \\
\text { Sp2 : } \\
\text { Melatih cara perawatan diri : berhias } \\
\text { Sp3 : } \\
\text { Melatih cara perawatan diri : makan/minum } \\
\text { Sp4 : } \\
\text { Melatih cara perawatan diri : BAK/BAB }\end{array}$ \\
\hline
\end{tabular}

3.15Implementasi Dan Evaluasi Keperawatan

\begin{tabular}{|l|l|l|}
\hline Hari/tgl & \multicolumn{1}{|c|}{ Implementasi } & \multicolumn{2}{|c|}{ Evaluasi } \\
\hline $\mathbf{3 1}$ & 1. Data & $\mathbf{S}:$ Senang \\
Januari & Tanda dan gejala : & $\mathbf{O}:$ \\
$\mathbf{2 0 2 2}$ & & - pasien mampu mengenali \\
$\mathbf{1 4 : 3 0}$ & & halusinasi yang dialaminya: \\
\hline
\end{tabular}




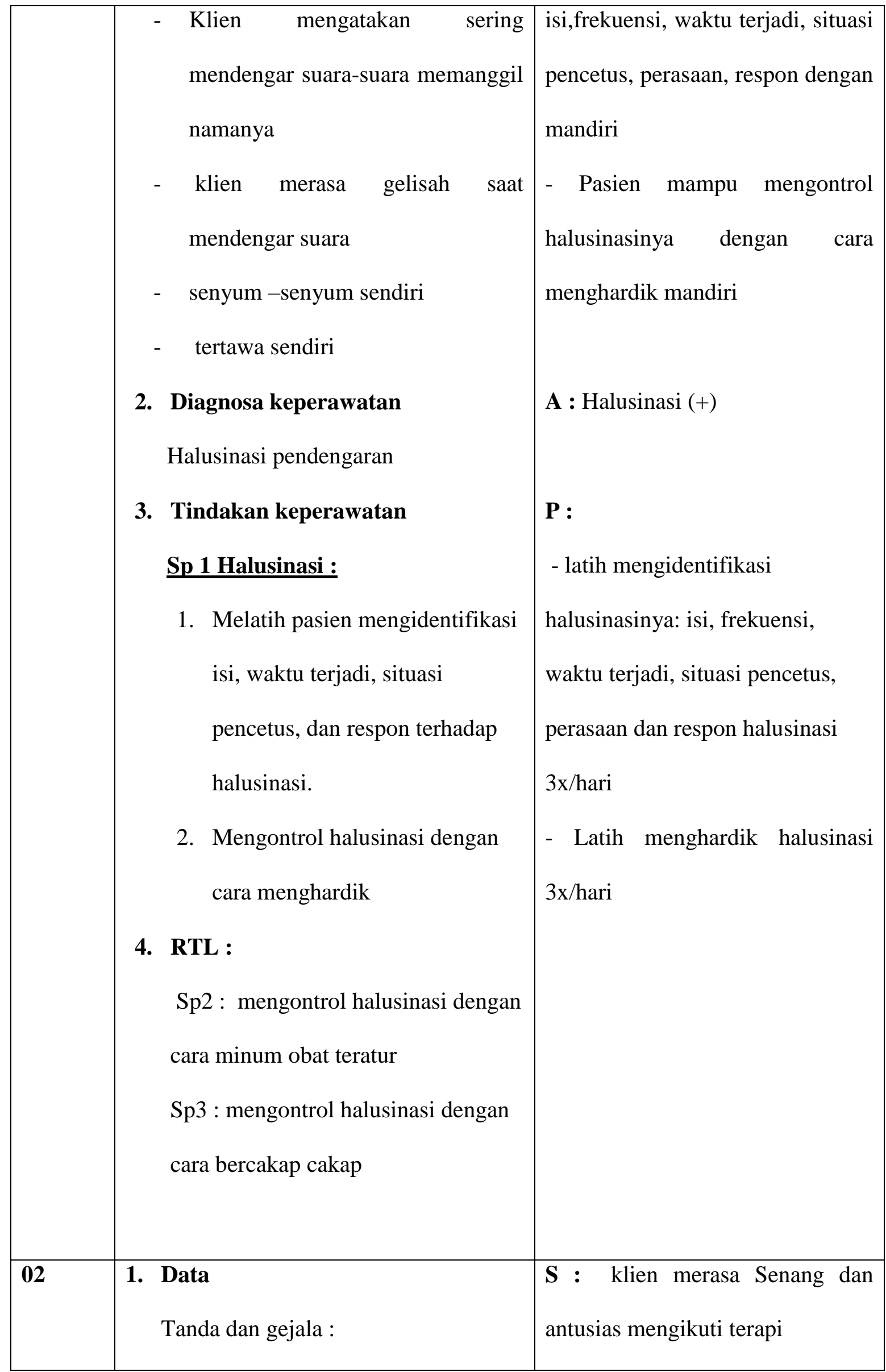




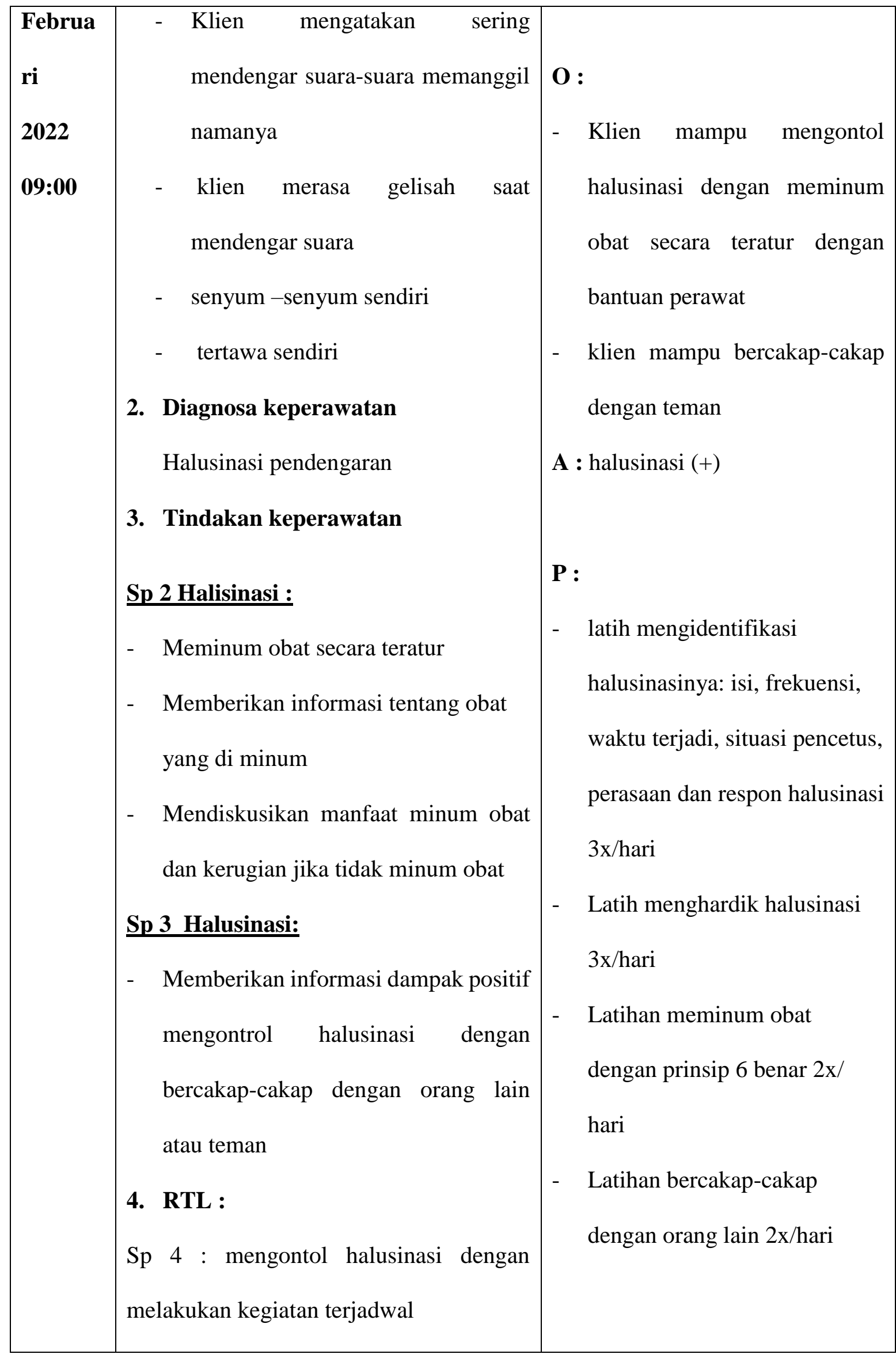




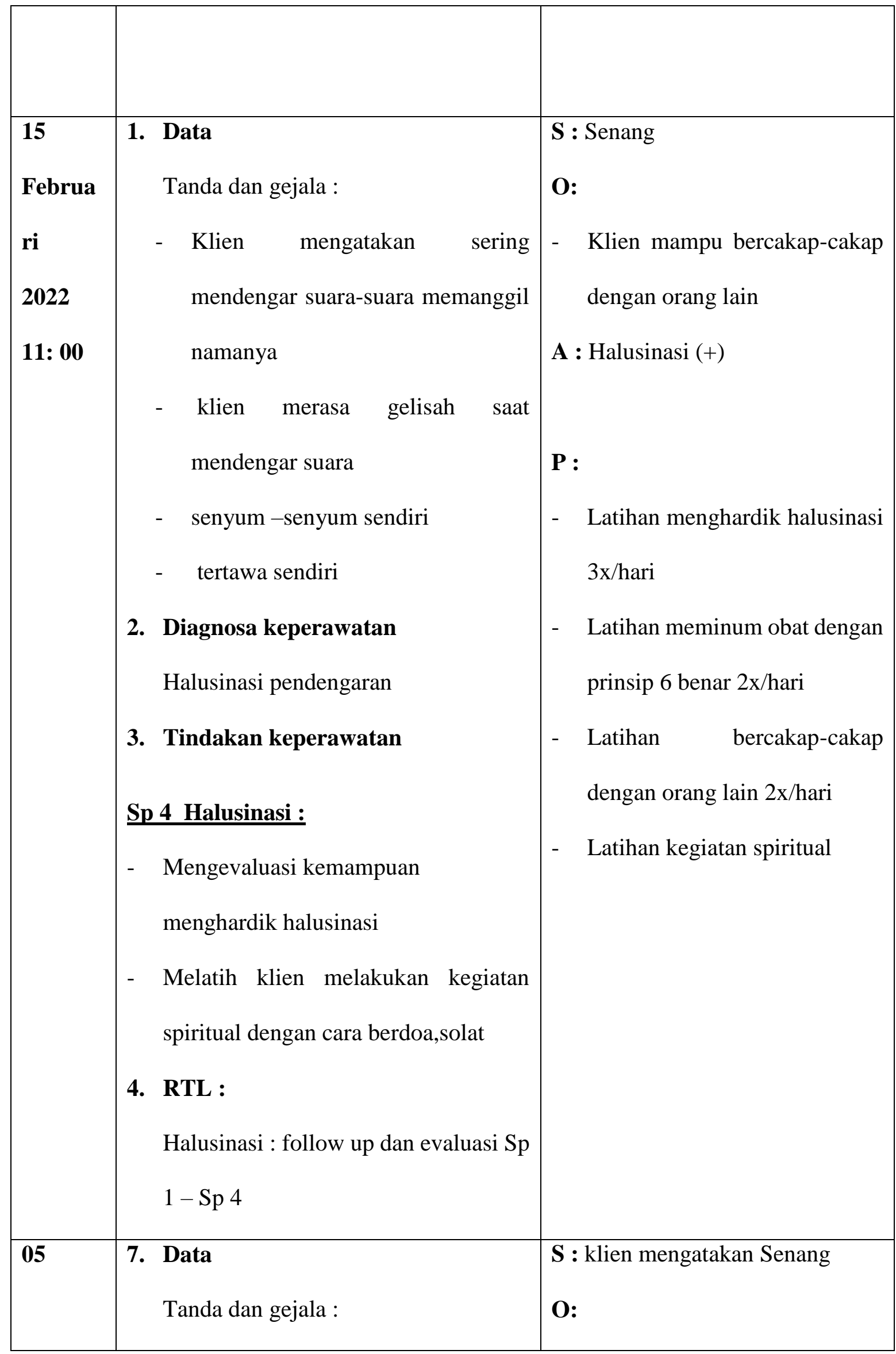




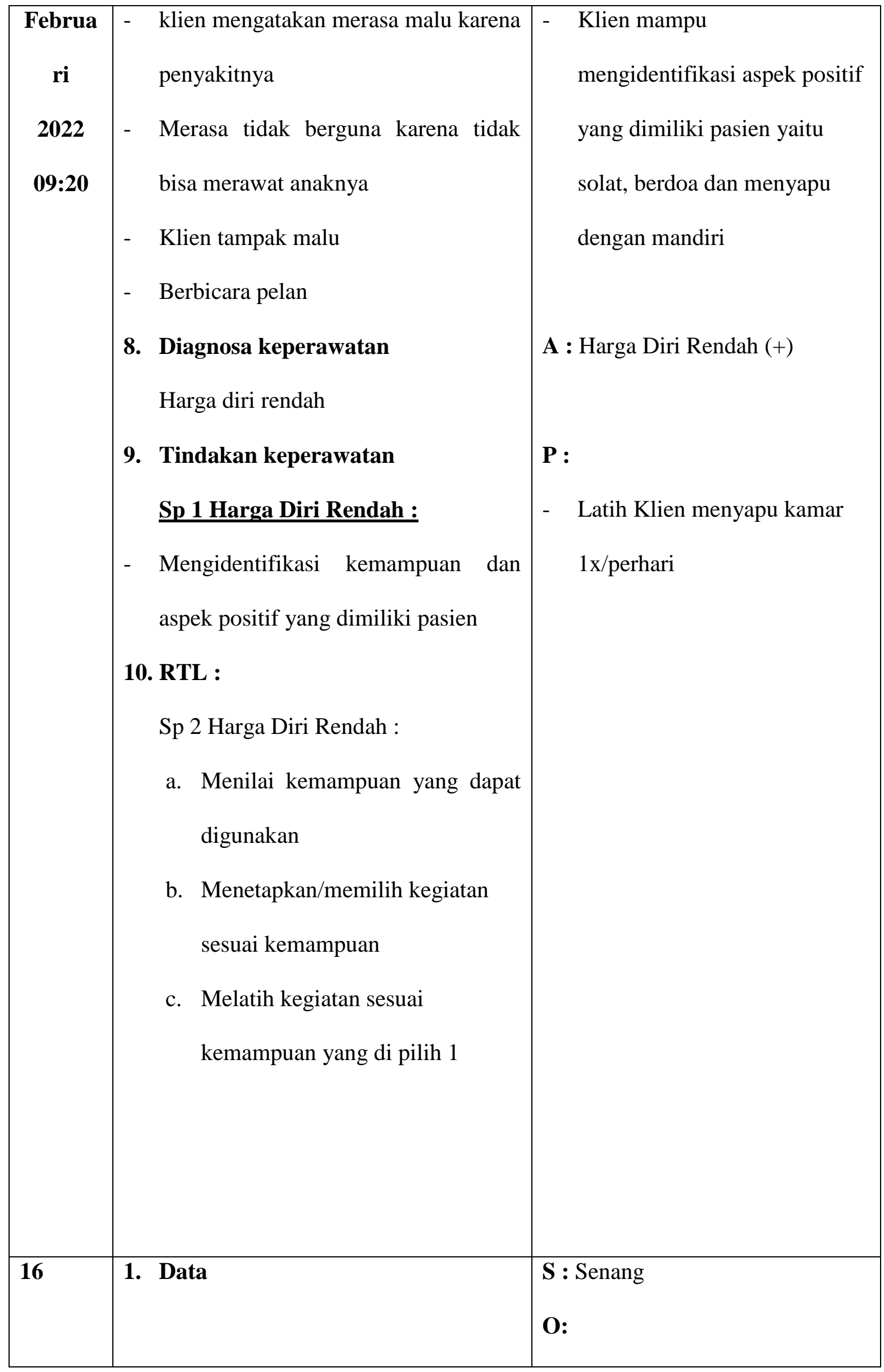




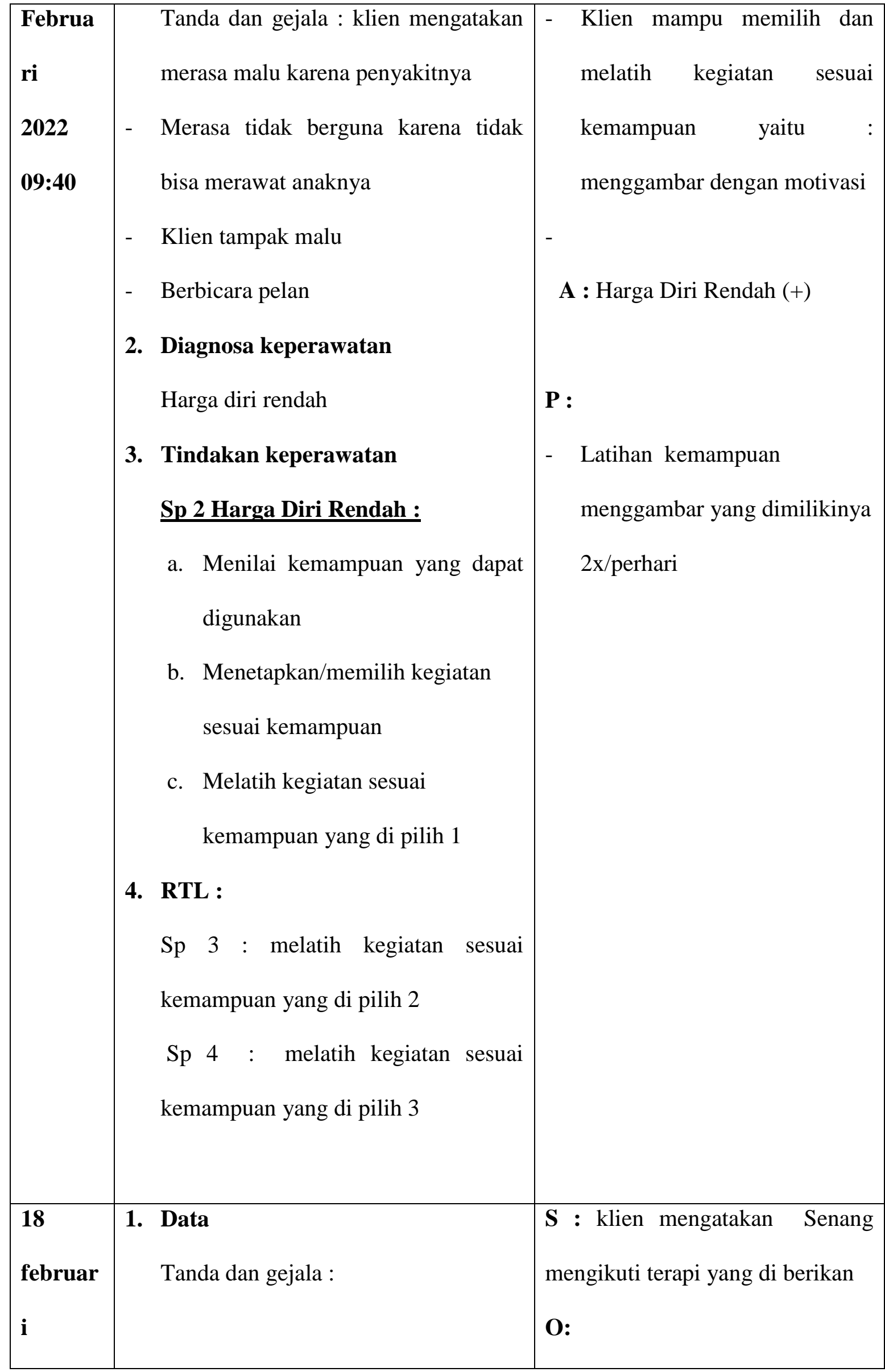




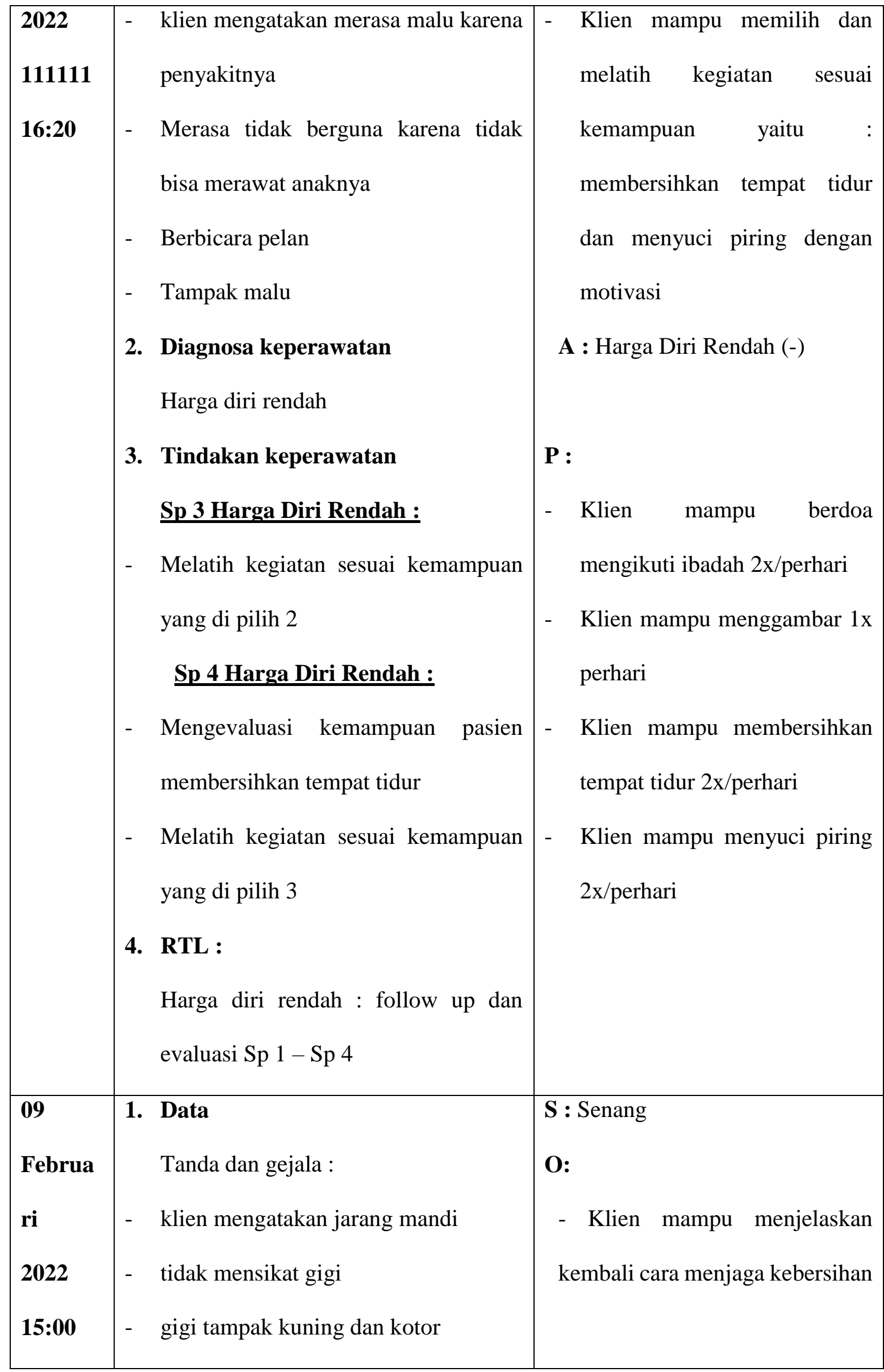




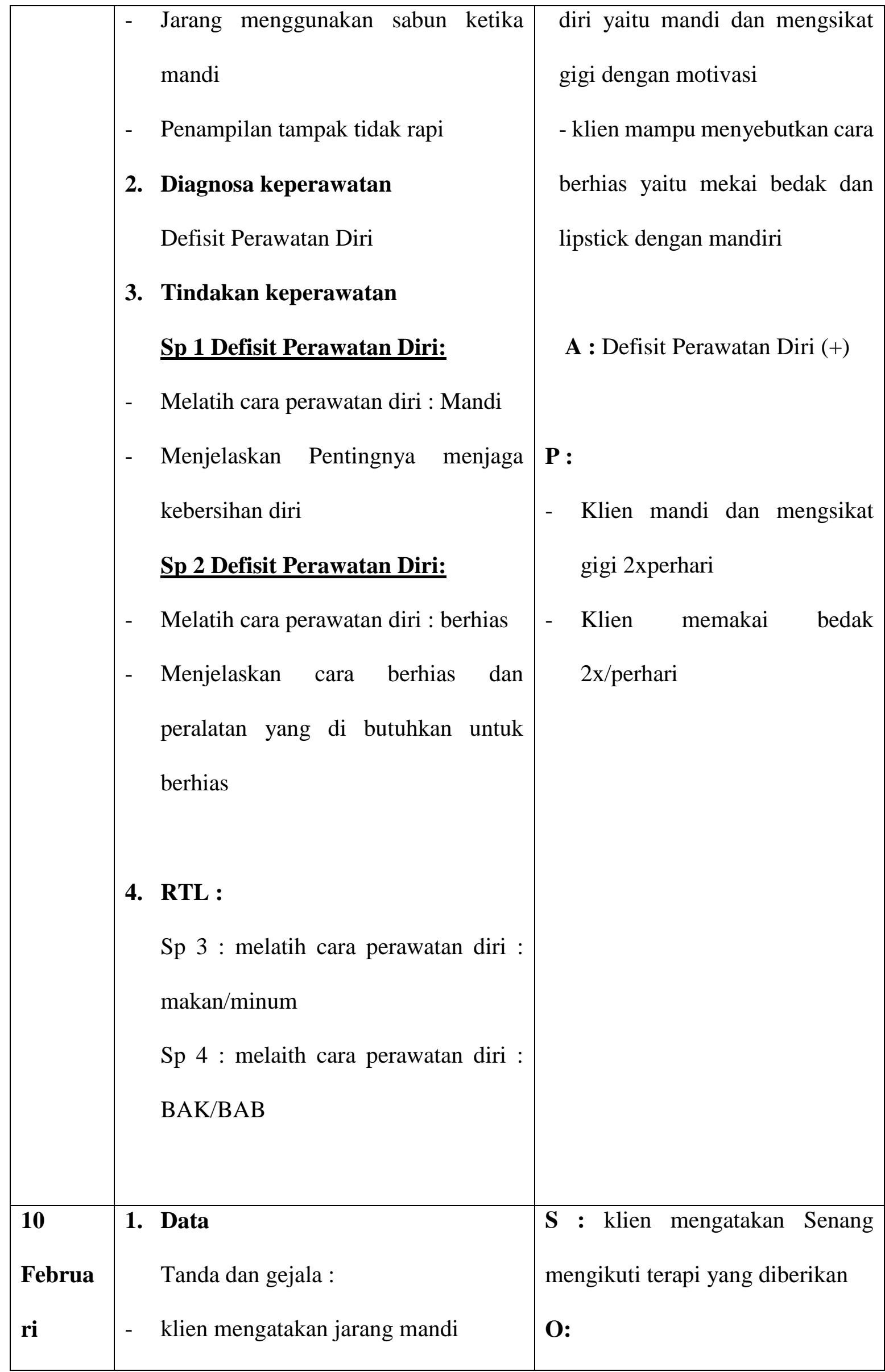




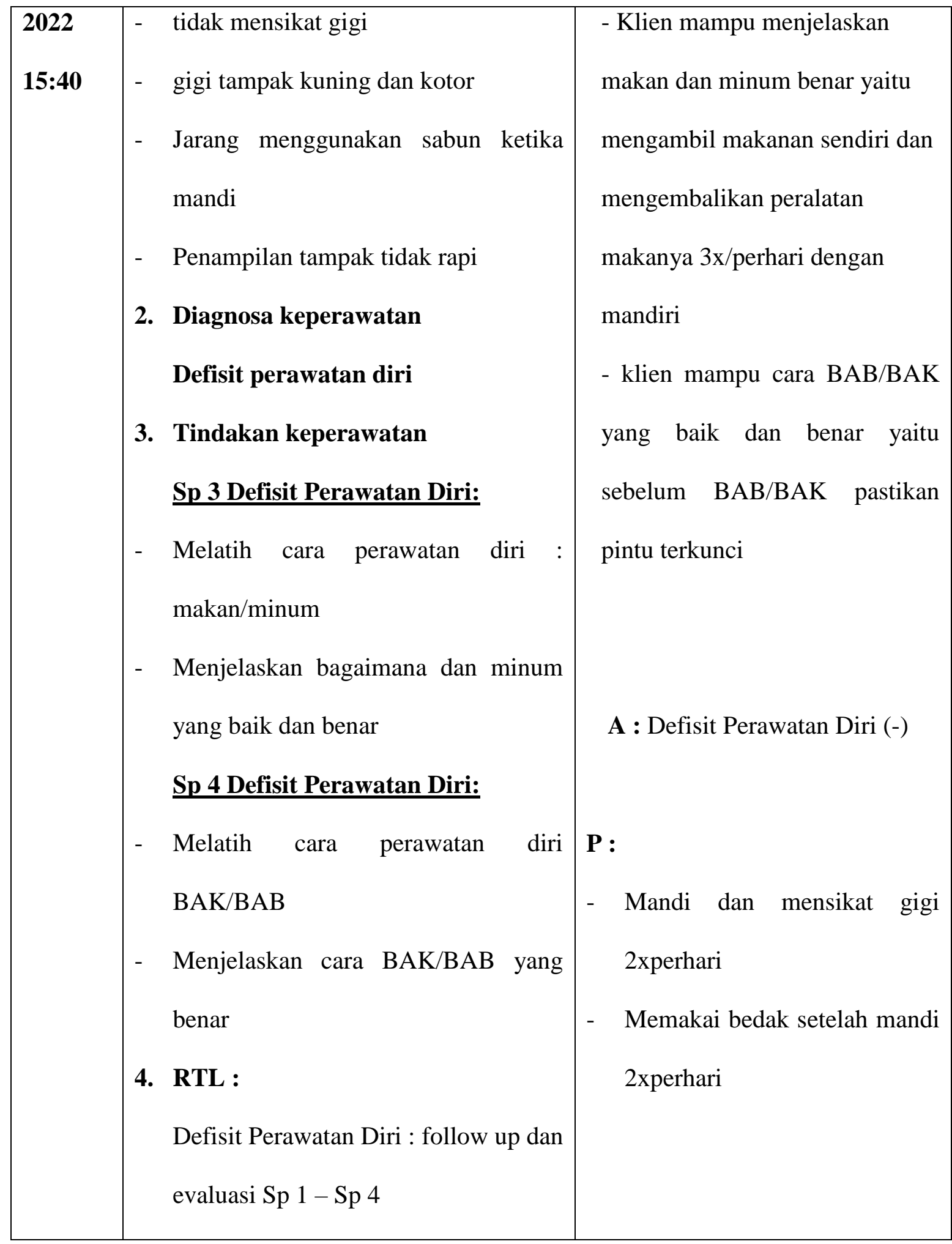




\section{BAB 4 \\ PEMBAHASAN}

Setelah penulis melaksanakan asuhan keperawat kepada Ny. D dengan gangguan persepsi sensori : halusinasi pendengaran di ruang Mawar, maka penulis pada BAB ini akan membahasan kesenjangan antara teoritis dengan tinjauan kasus. Pembahasan dimulai melalui tahapan proses keperawatan yaitu pengkajian, diagnosa keparawatan, perencanaan, pelaksanaan dan evaluasi.

\subsection{Tahap pengkajian}

Selama pengkajian dilakukan pengumpulan data dari beberapa sumber yaitu dari pasien dan pegawai rumah sakit. Mahasiswa mendapat sedikit kesulitan dalam menyimpulkan data kerena keluarga pasien jarang mengkunjungi pasien di ruang Mawar. Maka mahasiwa melakukan pendekatan pada pasien melalui komunikasi terapeutik yang lebih terbuka membantu pasien untuk memecahkan perasaannya dan juga melakukan observasi kepada pasien. Ada pun upaya tersebut yaitu :

a. Melakukan pendekatan dan membina hubungan saling percaya diri pada pasien agar pasien lebih terbuka dan lebih percaya dengan menggunakan perasaan.

b. Mengadakan pengkajian pasien dengan wawancara

c. Mengadakan pengkajian dengan cara membaca status, melihat buku rawatan dan bertanya kepada pegawai ruangan mawar.

Dalam pengkajian ini, penulis menemukan kesenjangan karena ditemukan. Pada kasus Ny. D, klien mendengar suara-suara memanggil namanya, gelisah, mondar-mandir, tampak tegang, putus asa, sedih dan lain-lain. Gejala gejala yang muncul tersebut tidak semua mencakup dengan yang ada di teori klinis dari halusnasi (Keliat,.2015). Akan tetapi terdapat faktor predisposisi maupun presipitasi yang menyebabkan kekambuhan penyakit yang dialami oleh Ny.D

\subsection{Diagnosa keperawatan}

Pada Teori Halusinasi (NANDA, 2015-2017), diagnosa keperawatan yang muncul sebanyak 3 diagnosa keperawatan (Aji, 2019) yang meliputi:

1. Halusinasi

2. Harga diri rendah 


\section{Defisit perawatan diri}

\subsection{Tahap perencanaan}

Perencanaan dalam proses keperawatan lebih di kenal dengan asuhan keperawatan yang merupakan tahap selanjutnya setelah pengkajian dan penentuan diagnosa keperawatan. Pada tahap perencanaan mahasiswa hanya menyusun rencana tindakan keperawatan halusinasi. Pada tahap ini antara tinjauan teoritis dan tinjauan kasus di temukan kesenjangan sehingga mahasiswa dapat melaksanakan tindakan seoptimal mungkin di dukung dengan seringnya bimbingan dengan pembimbing. Secara teoritis digunakan secara strategi pertemua sesuai dengan diagnosa keperawatan yang muncul saat pengkajian. Adapun upaya yang digunakan mahasiswa ialah :

1. Halusinasi

a. Mengidentifikasi halusinasi, isi, frekuensi, waktu terjadi, situasi pencetus, perasaan dan respon halusinasi

b. Mengontrol halusinasi dengan cara menghardik

c. Memberikan informasi tentang oabt yang di minum

d. Mendiskusikan maanfaat minum obat da kurugiaan jika tidak meminum obat

e. Memberikan informasi dampak positif negonrol halusinasi dengan cara bercakapcakap dengan orang lain

f. Melatih cara mengontrol halusinasi dengan melakukan kegiatan terjadwal

5. Harga diri Rendah
a. Mengidentifikasi kekmampuan dan aspek positif yang dimiliki klien
b. Membantu klien menilai kegiatan sesuai kemampuan
c. Membantu klien menetapkan kegiatan sesuai kemampuan
d. Membantu klien melatih kegiatan sesuai kemampuan yang di pilih 1
e. Membantu klien melatih kegiatan sesuai kemampuan yang di pilih 2
f. Membantu klien melatih kegiatan sesuai kemampuan yang di pilih 3

6. Defisit perawatan Diri

a. Membantu klien melatih cara perawatan diri : mandi

b. Membantu klien melatih cara perawatan diri : berhias

c. Membantu klien Melatih cara perawatan diri : makan/minum

d. Membantu klien Melatih cara perawatan diri : BAB/BAK 


\subsection{Tahap implementasi}

Implementasi adalah tahap dimana perawat memulai melakukan tindakan penulisan hanya mengatasi halusinasi pendengaran ( Aldam \& Wardani, 2019).Pada diagnosa keperawatan halusinasi yang dilakukan strategi pertemuan pertama yaitu : melatih mengidentifikasi isi, waktu terjadi, situasi pencetus dan respon halusinasi, mengontrol halusinasi dengan cara menghardik, strategi pertemuan kedua memberikan informasi tentang obat yang di minum, mendiskusikan manfaat minum obat, memebrikan informasi dampak positif mengontol halusinasi dengan cara bercakap-cakap dengan orang lain, strategi pertemuan ke tiga melatih klien melakukan kegiatan spiritual dengan cara berdoa dan solat.

\subsection{Tahap evaluasi}

Pada tahap tinjauan teoritis evaluasi yang diharapkan adalah : Pasien mempercayai perawat sebagai terapis, Pasien Dapat mengidentifikasi halusinasi, Pasien dapat mengendalikan halusinasi, Latihan bercakap-cakap dengan orang lain (teman), Meminum obat secara teratur (Hafizzudin, 2021).

Pada tinjauan kasus evaluasi yang di hasilkan adalah : Klien mampu mengontrol dan mengidentifikasi halusinasi, Klien mampu mengontrol halusinasi dengan meminum obat secara teratur, Klien mampu melakukan latihan bercakap-cakap dengan orang lain, Klien mampu memahami benar obat 


\section{BAB 5}

\section{PENUTUP}

\subsection{Kesimpulan}

Proses keperawatan merupakan metode ilmiah dalam menjalankan proses keperawatan dan menyelesaikan masalah sistematis yang digunakan oleh perawat dan peserta didik keperawatan, Setelah menguraikan tentang proses keperawatan Ny.D disimpulkan bahwa pasien dapat mengontrol halusinasi dengan terapi yang di ajarkan. Dimana pasien dapat menghardik halusinasi,meminum obat secara teratur, bercakap-cakap dengan orang lain, dan melakukan kegiatan yang sudah di jadwalkan sehingga bisa di terapkan.

1. Pengakajian yang dilakukan tidak banyak berbeda dengan pengakajian teoritis dan penulis tidak mendapat kesulitan dalam pengkajian yang dilakukan

2. Dalam mengatasi masalah yang dihadapi klien, mahasiswa mampu menyusun tindakan keperawatan sesuai dengan teoritis yang ada

3. Dalam pelaksanan tindakan keperawatan disesuaikan dengan perencanaan dan dapat di laksananakan walaupun belum sepenuhnya dapat terlaksanakan

4. Pada tahap evaluasi masalah yang dihadapi klien tidak teratasi semua sesuai dengan masalah klien

\subsection{Saran}

1. Bagi mahasiswa

Hendaknya mahasiswa/i dapat melakukan askep sesuai dengan tahapan-tahapan dari Standar Operasional Prosedur (SOP) dengan baikn dan benar yang diperoleh selama masa pendidikan baik akademik maupun lapangan praktek.

2. Bagi pasien halusinasi

Diharapkan pasien dapat menerapkan terapi yang telah di berikan baik secara medik maupun secara terapi keperawatan yang telah digunakan demi pencapaian penyembuhan penyakit dengan masalah gangguan jiwa.

3. Bagi perawat

Diharapkan dapat menerapkan komunikasi traupetik dalam pelaksanaan strategi pertemuan 1-3 pada klien halusinasi sehingga mempercepat proses pemulihan 


\section{Bagi keluarga}

Agar keluarga selalu memberikan motivasi kepada klien dan juga perawatan dengan halusinasi

5. Bagi institusi pendidikan

Dapat meningkatkan bimbingan klinik kepada mahasiswa profesi ners sehingga mahasiswa semakin mampu dalam melakukan asuhan keperawatan.

6. Bagi rumah sakit

Laporan ini diharapkan dapat menjadi acuan dan referensi dalam memebrikan asuhan keperawatan pada klien dengan halusinasi 


\section{DAFTAR PUSTAKA}

1. Aldam, S. F. S., \& Wardani, I. Y. (2019). Efektifitas penerapan standar asuhan keperawatan jiwa generalis pada pasien skizofrenia dalam menurunkan gejala halusinasi. Jurnal Keperawatan Jiwa (JKJ): Persatuan Perawat Nasional Indonesia, 7(2), 165-172.

2. Afnuhazi \& Ridhyalla. (2015). Komunikasi Terapeutik Dalam Keperawatan Jiwa.

3. Dermawan, Deden \& Rusdi. (2016). Keperawatan jiwa : Konsep Dan Merangka Kerja Asuhan Keperawatan Jiwa. Yogyakarta : Pustaka Baru

4. Ervina,I., \& Hargiana, G. (2018). Aplikasi keperawatan Generalis dan Psikoreligius pada pasien pada gangguan sensori persepsi: Halusinasi penglihatan dan pendengaran. Jurnal Riset Kesehatan Nasional, 2(2), 114-123. http://dx.doi.org/10.37294/jrkn.v2i2.106

5. Pardede, J. A. (2020). Decreasing Hallucination Response Through Perception Stimulation Group Activity Therapy In Schizophrenia Patients. Iar Journal of Medical Sciences, 1(6), 304-309.

6. Pardede, J. A., \& Siregar, R. A. (2016). Pendidikan Kesehatan Kepatuhan Minum Obat Terhadap Perubahan Gejala Halusinasi Pada Klienskizofrenia. Mental Health, 3(1).

7. Pardede, J. A. (2020). Beban Keluarga Berhubungan Dengan Koping Saat Merawat Pasien Halusinasi. Jurnal Ilmu Keperawatan Jiwa, 3(4), 445-452.

8. Pardede, J. A., Siringo-ringo, L. M., Hulu, T. J., \& Miranda, A. (2021). Edukasi Kepatuhan Minum Obat Untuk Mencegah Kekambuhan Orang Dengan Skizofrenia. Jurnal Abdimas Mutiara, 2(2), 1-5.

9. Keliat \& Akemat (2015), Model Praktik Keperawatan Profesional Jiwa, Jakarta: EGC

10. Keliat, B. A., dkk (2020). Asuhan keperawatan jiwa. Jakarta : Penerbit Buku Kedokteran EGC.

11. Kemenkes RI. (2018). Laporan Nasional Rist Kesehatan Dasar (riskesdas). Jakarta : Badan Penelitian dan Pengembangan Kesehatan

12. Manao, B. M., \& Pardede, J. A. (2019). Correlation of Family Burden of The Prevention of Recurrence of Schizophrenia Patients. Mental Health, 4(1), 31-42.

13. Muspidayanti, M. (2018). Asuhan keperawatan [pada Tn D denga halisinasi pendengaran di wilayah kerja puskesmas tarusan kab. pesisir zselatan tahun 2018 (Doctoral dissertation, STIKes Perintis Padang).

14. Shimomai, K., Furukawa, H., Kuroda, Y., Fukuda, K., Masuda, M., \& Koizumi, J. (2018). The difficulty of selecting the NANDA-I nursing diagnosis (2015-2017) of "Death Anxiety" in Japan. International journal of nursing knowledge, 29(1), 4-10.

15. Pardede, J. A., Keliat, B. A., \& Yulia, I. (2015). Kepatuhan dan Komitmen Klien Skizofrenia Meningkat Setelah Diberikan Acceptance And Commitment Therapy dan Pendidikan Kesehatan Kepatuhan Minum Obat. Jurnal Keperawatan Indonesia, 18(3), 157-166.

16. Pardede, J. A., \& Hasibuan, E. K. (2020). Lamanya Perawatan Pasien Skizofrenia Rawat Jalan Dengan Tingkat Stres Keluarga. Indonesian Trust Health Journal, 3(1), 283-288. https://doi.org/10.37104/ithj.v3i1.49

17. Pardede, J. A., Silitonga, E., \& Laia, G. E. H. (2020). The Effects of Cognitive Therapy on Changes in Symptoms of Hallucinations in Schizophrenic Patients. Indian Journal of Public Health Research \& Development, 11(10).

18. Pardede, J. (2020). Family Knowledge about Hallucination Related to Drinking Medication Adherence on Schizophrenia Patient. Jurnal Penelitian Perawat 
Profesional, 2(4), 399-408. https://doi.org/10.37287/jppp.v2i4.183

19. Pardede, J. A. (2020). Family Burden Related to Coping when Treating Hallucination Patients. Jurnal Ilmu Keperawatan Jiwa, 3(4), 453-460. http://dx.doi.org/10.32584/jikj.v3i4.671

20. Purba, W. V. (2021). Studi Kasus: Asuhan Keperawatan Jiwa Pada Ny. A Dengan Masalah Halusinasi Penglihatan.

21. Prabowo, A. Y., Estiasih, T., \& Purwantiningrum, I. (2014). Umbi Gembili (Dioscorea esculenta L.) Sebagai Bahan Pangan Mengandung Senyawa Bioaktif: Kajian Pustaka [In Press Juli 2014]. Jurnal Pangan dan Agroindustri, 2(3), 129-135.

22. Riskesdes. (2018) Riskesdes Skizofrenia https://www.who.int/news-room/factsheets/detail/schizophrenia. Di unduh Tanggal 24 Januari 2022

23. Setyanto, A. T., Hartini, N., \& Alfian, I. N. (2017). Penerapan Social Support untuk meningkatkan Kemandirian pada penderita Skizofrenia. Wacana, 9(1).

24. Santi, F. N. R., Nugroho, H. A., Soesanto, E., Aisah, S., \& Hidayati, E. (2021). Perawatan Halusinasi, Dukungan Keluarga Dan Kemampuan Pasien Mengontrol Halusinasi: Literature Review. Jurnal Keperawatan dan Kesehatan Masyarakat Cendekia Utama, 10(3), 271-284.

25. Sunarwanto, P. (2021). Laporan Studi Kasus Pada Pasien Dengan Perubahan Persepsi Sensori: Halusinasi Pendengaran Di Desa Krosok Gaden Kecamatan Trucuk Kabupaten Klaten (Doctoral Dissertation, Stikes Muhammadiyah Klaten).

26. Sutejo (2020). Keperawatan Kkesehatan Jiwa Prinsip dan Praktik Asuhan KeperawatanJiwa. Yogyakarta : Pustaka Baru

27. Stuart. Gail. W, Keliat. Budi. Anna,\& Pasaribu. Jesika.(2016). Keperawatan kesehal11tan jiwa: Indonesia : Elsever.

28. Word Health Organization, (2019). Schizophrenia. Retrieved from https://www.who.int/news-room/fact-sheets/detail/schizophrenia

29. Yusuf, A., PK, R. F., \& Nihayati, H. E. (2015). Buku ajar keperawatan Kesehatan Jiwa. Jakarta : Salemba.

30. Zelika, A. A., \& Dermawan, D. (2015). Kajian Asuhan Keperawatan Jiwa Halusinasi Pendengaran Pada Sdr. D Di Ruang Nakula RSJD Surakarta. Profesi (Profesional Islam): Media Publikasi Penelitian, 12(02). 